\title{
To "Move, Surprise, and Thrill": Thirty Years of Promoting Cultural Diversity in Norwegian School Concerts
}

\author{
Jan Sverre Knudsen
}

\begin{abstract}
This chapter examines how a politics of cultural diversity was implemented over a 30-year period in a Norwegian school concert program run by Concerts Norway. Departing from a historical overview, the chapter outlines the shifting agendas, values, and visions of diversity that governed this ambitious cultural effort. A central aim is to examine the ideological positions that influenced the program and the political and educational debates surrounding it. The concert program is discussed with respect to cultural diversity and anti-racism, democracy, tradition, hybridity, and the tensions between educational and artwork-based paradigms. Based on theorizations of cultural difference, the chapter shows how promoting music to children has been understood as an important part of shaping societal attitudes and laying the grounds for an anti-oppressive education. Critical issues regarding representation, influence, and power in the staging of music involving immigrant performers are raised. The chapter relates the concert programs to the political frames and ideals of the nation-state by illustrating how international cooperation effectively made the concert programs a part of Norwegian foreign policy. It points out how changing government policies had a profound impact on programs promoting cultural diversity, eventually leading to their termination as a national cultural strategy.
\end{abstract}

Keywords School concerts $\cdot$ Difference $\cdot$ Tradition $\cdot$ Hybridity $\cdot$ Anti-racism $\cdot$ State policies $\cdot$ Immigration

\footnotetext{
J. S. Knudsen ( $ه)$

Faculty of Education and International Studies, Oslo Metropolitan University, Oslo, Norway

e-mail: jansk@oslomet.no
} 


\section{Introduction}

For nearly three decades ${ }^{1}$, all public primary schools in Norway were involved in concert programs that aimed to promote cultural diversity. The government organization Concerts Norway (CN, Rikskonsertene) was responsible for the production of more than 9000 concerts each year with visiting professional musicians. This implied that practically all school pupils in Norway-more than 600000 children-attended at least 2 concerts annually during school hours. Programs involving music from non-Western cultures, especially music related to immigrant groups, comprised about $15 \%$ of the total concert portfolio on average but were unquestionably the hallmark of CN. A policy of cultural diversity was highlighted in marketing, web pages, and publications; it shaped the image of the institution and contributed strongly to its political legitimacy both in Norway and in international cooperation. The intention of this chapter is to examine this extraordinary cultural effort in view of a politics of diversity and the ideological positions it was influenced by.

The promotion of live music to children in an educational setting must be regarded as an embodiment of cultural and social values. The visiting school concert programs were governed by particular ideologies of musical value and cultural diversity (Green 2003). The key concepts used by the programs, multicultural and cultural diversity, are social constructions, continuously subject to negotiations and changes $^{2}$. How they have been understood during the 30-year history of the concert programs discussed here is the result of the discourses they are shaped by and contribute to shaping. As a major government-funded institution with substantial power, $\mathrm{CN}$ was a key contributor to public debates and discussions and to the shaping of these concepts through words and cultural practices.

As a background for a discussion of $\mathrm{CN}$ policies and practices, it can be useful to draw upon theorizations of cultural difference. Thinking in terms of differences is a fundamental cognitive strategy for learning, understanding, and identification. In an educational setting, it is necessary to carefully examine the consequences of thematizing, configuring, and promoting difference (Kumashiro 2002). Differences are produced through discourse, policies, and practices. As Kofi Agawu (2003) argues, differences are created, not given, and play an important role in the building of cultural stereotypes and negotiations of power, sometimes through coarse and fake images of culture and music (Agawu 2003). Lundberg et al. (2003) present a contrasting, but equally relevant, perspective by pointing to the necessary-and generally beneficial-production of difference through music in a culturally diverse Sweden. For minorities and other marginal communities, their self-definition as distinct from the surrounding world is vital for their survival as cultural entities.

\footnotetext{
${ }^{1}$ 1987-2016. The cultural diversity efforts started in 1987 and were in practice terminated in 2016 when Concerts Norway was shut down and concert programs were transferred to Arts for Young Audiences in Norway (AYAN; Kulturtanken).

${ }^{2}$ Both the terms multicultural and cultural diversity are used, reflecting the terminology employed by $\mathrm{CN}$.
} 
Marking cultural difference is essential in order to be seen and heard by others and paid attention to in society at large. Music "can be used as a means of expressing we are different, we are an ethnic group, we have our own culture" (Ronström 1995, p. 7).

In music education, the crucial point concerns the ways in which we address and contextualize difference and how children's engagement with diverse music traditions can play a part in the building of an inclusive, anti-oppressive education (Kumashiro 2002). This relates closely to the aims and strategies of CN. The concert programs discussed in this chapter involved the construction, marking, and maintenance of cultural differences in various ways, but at the same time, they involved developing strategies for understanding and engaging with difference through participatory musical experiences.

There is a substantial body of research related to the $\mathrm{CN}$ school concert programs (e.g., Bamford 2012; Borgen and Brandt 2006; Breivik and Christophersen 2013; Holdhus 2019; Holdhus and Espeland 2013), but only a few publications have explicitly addressed the cultural diversity efforts (Bergh 2007; Knudsen 2013; Skyllstad 1993 2004; Vandvik 2018). Although there are hardly any programs of similar dimensions or scope outside Scandinavia, there are several relevant publications on the role of teaching artists in schools (e.g., Booth 2009; Rabkin 2011).

In the remainder of this chapter, I first give an introduction to the school concert format and a historical overview of the $\mathrm{CN}$ cultural diversity efforts and the closely related international programs. This is followed by discussions concentrating on key issues of the school concert discourse, namely, cultural diversity and anti-racism, democracy, hybridity and the tensions between educational and artwork-based paradigms. The research material consists of documents, reports, webpages, and scholarly publications, as well as three interviews with $\mathrm{CN}$ organizers conducted in 2018. Experiences from Fargespill, a recent artistic program built on similar ideals, are included to supplement the discussion (Hamre et al. 2012; Kvaal 2018).

\section{The School Concert}

Over the years, $\mathrm{CN}$ developed and refined a specific visiting school concert format. Concert groups were small, including two or three performers as the norm. They were either selected through auditions or headhunted by $\mathrm{CN}$, and they always underwent a production process for tailoring their performance to the format and requirements of playing successfully for child audiences. Before a concert, schools would receive information about the performers and some teaching material in the form of recordings, sheet music, or suggested activities for preparations in class. The typical concert took place in the school gym. Concerts were "unplugged" or used simple, portable amplification. There was close interaction between pupils and performers; everyone was on the floor, on the same level. Performers would often make use of dramatic forms, moving around among the audience, addressing children directly through musical sounds and body movements, and inviting them 
to participate actively in songs, dances, or other activities. After the concert, children could spend some time engaging with the musicians, chatting, asking questions, or becoming acquainted with the instruments.

\section{Historical Overview}

CN was established in 1968 as a government institution under the Department of Culture based on the ambition of promoting live music of high artistic quality to the entire population, especially in the rural areas rarely visited by major artists. From the beginning, concerts for children during school hours were a major part of the programs. Soon, all public schools were included, offering more than $96 \%$ of all children in Norway two concerts a year. The national education plan of 1987 established visiting school concerts as a compulsory part of Norwegian music education (Vandvik 2018).

As labor immigration to Norway increased during the 1970s and 1980s, the presence of immigrant culture became noticeable. Cultural programs and education policies soon became influenced by political debates on integration. In 1987, CN made the promotion of immigrant music a special focus area, an effort explicitly aimed at counteracting racist attitudes. A close cooperation with immigrant communities was initiated, both in the concert programming and the development of teaching material.

The early "multicultural" school concerts were soon linked to The Resonant Community (Klangrikt Fellesskap), a 3-year research project (1989-1992) based at the University of Oslo. The objective was to map schoolchildren's attitudes toward "otherness" in relation to their participation in music activities involving immigrant music cultures. The results were presented as overwhelmingly positive, indicating that in schools with the most intensive music programs, the prevalence of bullying and racist attitudes was substantially reduced and that minority pupils experienced increased respect for their cultural identity (Skyllstad 1993). The report from the project inspired various related programs in the following years.

Immigrants" music and other "world music" soon became an integrated part of school concert programs. Many performers were recruited through CN's Multicultural Music Centre (1992-2001) and the Ethnic Music Cafés-informal concert arenas featuring immigrant musicians. In 1994, CN initiated the Oslo World Music Festival, which from 1999 included activity programs for children called "Children's Art Exploration" (Barnas verdensdager). In 2001, school concerts became part of The Cultural Rucksack (Den kulturelle skolesekken), a national program for visiting artists, which also involved other art forms than music (Breivik and Christophersen 2013).

As the ideas of cultural diversity in music promotion took hold, $\mathrm{CN}$ became involved in international work, as consultants and organizers for the Ministry of Foreign Affairs and the Norwegian Agency for Development Cooperation (NORAD). From 2000, long-term contracts were signed involving music 
cooperation and cultural exchange with South Africa, India, and Palestine and, eventually, China, Nepal, Sri Lanka, Pakistan, Brazil, Jordan, and Bangladesh.

In 2001, the Multicultural Music Centre was shut down. A new international unit, and later a separate international department, took over most of CN's international work, including the promotion of artists from cooperating countries. In 2016, following a process of decentralization and changing national policies, $\mathrm{CN}$ was officially closed, and the school concert programs were transferred to a new organization, namely, Arts for Young Audiences in Norway (AYAN) ${ }^{3}$. This implied a broadening of visiting artist programs in schools through the inclusion of theatre, visual arts, and literature; at the same time, it inevitably led to a reduced focus on the potentials of music in the promotion of cultural diversity. The dominant position music had had in this kind of work for more than 30 years was challenged. Today, there is no national strategy for promoting cultural diversity in school concerts.

\section{National and International Policies}

In a Nordic context, policies of cultural diversity are inseparable from a history of equality and democracy as defining values of the nation-states (Andersson and Hilson 2009). The prevailing policy of cultural diversity in education is an ideology of national dimensions that legitimizes certain values and practices over others (Kallio and Väkevä 2017). The Norwegian cultural diversity efforts were part of a state policy, although $\mathrm{CN}$ organizers had considerable independence in their programming and planning. The programs enjoyed strong political recognition, especially from the labor governments. This is evident in official documents, for example, a parliamentary report from 2007 asserts that cultural diversity must be a "permanent dimension" of all visiting artist programs in schools (KKD 2007, pp. 45-46). Moreover, it is no coincidence that two Norwegian ministers of culture, Åse Kleveland and Turid Birkeland, served as CN directors after they left their government offices.

The international dimensions of the school concert programs were ambitious and wide ranging. Through cooperation with the Ministry of Foreign Affairs, school concerts effectively became a part of Norwegian foreign policy. The school concert model was "exported" in cooperation with local organizers, such as SAMRO ${ }^{4}$ in South Africa, Sabreen in Palestine, and SPIC MACAY ${ }^{5}$ in India (Korum 2019; Korum and Subramaniam 2020). School concerts were used as door openers for political and economic cooperation. The international music cooperation was governed by various agendas, including development aid, cultural rights, nation building, strengthening civil society, and, not least, the "state branding" of Norway

\footnotetext{
${ }^{3}$ The Norwegian name is Kulturtanken (The Culture Tank/Thought).

${ }^{4}$ The Southern African Music Rights Organization.

${ }^{5}$ Society for the Promotion of Indian Classical Music and Culture Amongst Youth.
} 
abroad. Norway was presented as a culturally diverse and egalitarian society based on the idea of a "national goodness regime" (Tvedt 2005, pp. 482), and concerts for children were an important part of this all along. Norwegian and immigrant musicians based in Norway would play for schools in cooperating countries, and at the same time, funding from the Ministry of Foreign Affairs and NORAD ${ }^{6}$ allowed CN to invite renowned musicians who attracted huge audiences in their home countries to play for Norwegian children, sometimes at small schools with less than 20 pupils in remote mountain communities.

While the concert programs taking place in Norway never met any major political opposition, the international programs were more vulnerable to political change. After the conservative alliance led by Erna Solberg came into power in 2013, there was a marked change of policy. CN's cooperation with the Ministry of foreign Affairs was downscaled and eventually discontinued. Performances by international guest musicians in Norwegian schools came to a halt. Concert promotion for children, and to a large extent, music exchange in general, was no longer considered part of Norwegian foreign policy and development aid.

\section{Cultural Diversity and Anti-racism}

In all the material from $\mathrm{CN}$, there is no clear definition of cultural diversity or multicultural. The terms are constructed discursively through documents, reports, promotion, and musical practice. Use of the terms is varied and sometimes overlapping, their connotations generally taken for granted. As a major state-funded institution, $\mathrm{CN}$ was an instrument of majority cultural dominance and hegemony-a knowledge-producing institution with the power to influence and shape the meaning of such terms.

From the very start, multicultural was the buzzword, with the establishment of the Multicultural Music Centre in 1992, and various school projects with names like "Multicultural Music Experiments" (Knudsen and Berkaak 1998). Gradually, there was a move from multicultural to cultural diversity as the preferred label. This reflected a general change in terminology in the cultural and political discourse. Arguably, multicultural became "burdened" by increasingly being understood as a term referring exclusively to non-Western immigrants, while cultural diversity suggested a wider scope of differences. Labelling Norway as a multicultural society basically meant that there are many immigrants living here, and a multicultural school was a school with a large number of pupils born in non-Western countries.

The multicultural discourse in music education was constructed as a response to the challenges of immigration. It was based on the acknowledgement of a "new reality": that through immigration, European countries had lost their "homogenous character," and there was a need to build a society where people of many different

\footnotetext{
${ }^{6}$ The Norwegian Agency for Development Cooperation.
} 
backgrounds could coexist and benefit from becoming acquainted with one another's cultures (Skyllstad 1993, p. 4). We may speak of a multicultural ideology based on commonly recognized ideas of human equality and social justice. The idea was that school concerts were to become cultural meeting points more than arenas for promoting Norwegian, or other Western music traditions. Obviously, in this area, the historical role of public education in the transmission and inculcation of a unified national heritage was challenged.

CN's involvement in cultural diversity can be traced back to the political climate of the late 1980s. Arne Holen, director of $\mathrm{CN}$ at that time, reports becoming frustrated when he heard some ugly, racist remarks on the subway following the 1987 general elections (Vandvik 2018). He decided to make a difference- - there was so much talk about multiculturalism, but nobody seemed to be doing anything about it. Inspired by anti-racist movements in Europe and organizations like SOS Rasisme, the first school programs with immigrant musicians were initiated. The pioneers of the Multicultural Music Centre were especially inspired by models and experiences of the Swedish school concert programs and the World Music School in Amsterdam (Schippers 2010).

In these early years, instrumental justifications dominated concert programs and reports. Music was understood as an efficient tool for building positive attitudes toward the Other (Knudsen and Berkaak 1998, p. 10; Skyllstad 1993; Vandvik 2018). Cultural knowledge and familiarity with "otherness" was presented as a vaccine against racism. However, spreading knowledge was only part of the strategy. The understanding of xenophobia and racism as resting on emotional rather than intellectual grounds supported the development of concert formats involving active audience participation: "Racism cannot be countered through information alone" (Skyllstad 1993, p. 5) and "action creates attitudes" (p. 7). Bodily and emotional experiences through hands-on involvement with music and dance were understood as most powerful in affecting children's attitudes and bridging cultural differences.

The results from the Resonant Community research project were taken to prove that "music works" as an efficient sociopolitical tool in education. While the antiracist agenda was gradually downplayed and replaced by more general formulations of the benefits of widening horizons and learning from others, this ideology was doubtlessly the bedrock of 30 years of promoting cultural diversity through music.

Developing pupils' attitudes is an explicit goal in Norwegian education policies in general. In national education plans, didactical goals are related to three pillars of competence: knowledge, skills, and attitudes (e.g., Kunnskapsdepartementet 2016). A primary mission of the school system is to develop attitudes of respect, understanding, equality, and environmental awareness (KUF 1996; Kunnskapsdepartementet 2006, 2016). National music education curricula refer to Norway as a culturally diverse society where music can promote "belonging to your own culture and cultural heritage," as well as "tolerance and respect for the culture of others" (Kunnskapsdepartementet 2006, p. 137).

Many of the early $\mathrm{CN}$ concert programs targeting pupils' attitudes involved specific, often exotifying constructions of difference. The 3-year Resonant 
Community research project exclusively promoted non-Western traditional music, with 1 year devoted to each of the continents of Asia, Africa, and Latin America. In reports and teaching material, familiar stereotypes prevail-Asian music is linked to myths, rites, and imagination, and African music is an expression of "contact with the earth and the mystical forces that support life," whereas Latin American music is seen as a fruitful synthesis, radiating vitality and reflecting "human decency and freedom" (Skyllstad 1993, p. 7). Parallels may easily be drawn here to some of the dominating presentations of non-Western music in school textbooks (Rønningen 2015) and in music scholarship - presentations that primitivize the Other through "fake and facile attributions" that maintain an imbalance of power (Agawu 2003, p. 231).

As $\mathrm{CN}$ gained more experience in the field, the most exoticizing stereotypes were replaced by more well-informed descriptions of non-Western music. When the Multicultural Music Centre was closed in 2002, it was based on the understanding that its mission was largely accomplished, since, by then, music from all over the world had become well incorporated into school concerts and other program areas. The decision could be seen as a step toward a more "diversified normality" in concert promotion, reducing the risk of reproducing insider/outsider dichotomies (Carson and Westvall 2016, p. 37). From this time on, all concerts underwent the same process of evaluation and production, without some of them being labelled as multicultural.

School concerts were intended to give children an experience that was differenta contrast to what they would encounter through commercial music promotion. A central idea was to counter the hegemony of Anglo-American popular culture in children's lives ${ }^{7}$. In a promotional DVD, CN director Åse Kleveland argued that many children had rather narrow experiences with culture in their home environments and that school concerts might contribute to widening the scope of children's experiences (Rikskonsertene 2009). A frequently used promotional phrase through most of CN's history was that concerts should "move, surprise and thrill" audiences (Vandvik 2018, p. 161).

Promoting performances for children involves marketing; it is necessary to "speak" to children in terms that raise their attention and interest, presumably leading to a successful concert. In teacher's introductions to the concerts, there was a dominating focus on cultural difference. For example, a primary school teacher introducing a performance with Indian kathak dancer Mahua Shankar and tabla player Mithilesh Kumar Jha would tell the children that they were about to meet some "colorful and exciting visitors" from a culture that is "very different," playing instruments that are "very unfamiliar," while at the same time highlighting the quality and reputation of the musicians (Knudsen 2013, p. 175).

While it is always difficult to pinpoint how a concert experience with any unfamiliar music affects children (Knudsen 2013), it is necessary to consider issues

\footnotetext{
${ }^{7}$ Interview with Tom Gravlie, head of CN's Multicultural Music Centre, 5 April 2018.

${ }^{8}$ Berøre, overraske og begeistre.
} 
of status and power surrounding the event. A school concert is sanctioned by the school and teachers through information and preparations in class. The musicians are welcomed and introduced by an adult with authority — a teacher or the headmasteran act that symbolically transmits authority to the performers. In the most successful concerts, the school manages to create an atmosphere of respect, dignity, and appreciation for cultural expressions that most of the children have never witnessed before. While the music styles and performance modes may be unfamiliar, children are always affected by professionalism and artistic quality.

Interestingly, young children's reflections on their concert experience may also seem to concentrate on issues of difference. My conversations with school children (grades 1-3) following immediately after performances with Hindustani music and dance indicated a special focus on difference and novelty. When children were given the opportunity to meet the musicians, their first questions and comments would typically focus on aspects of the performance that were unfamiliar - the strange, different, and extraordinary: "Why do you have a red mark on your forehead?", "Why are you dancing barefoot?", "Why are you wearing those bells on your feet?", "Do you have to wear all that jewelry?", and "Does it hurt your fingers to play [tabla drums] that fast?” (Knudsen 2013, p. 175).

\section{Democracy}

The visiting school concert programs were rooted in a democratic vision based on the idea that all children have a right to engage with art and culture, as promoted, for example, in the UN Convention on the Rights of the Child (UN General Assembly 1989). This corresponds with the "civilizing mission" of Norwegian cultural policies and art programs (Bjørnsen 2009, p. 382), as well as CN's goal of promoting art experiences of high artistic quality to all children, regardless of social or economic background. Still, there are aspects of the activity that are far from democratic. Participation in the programs was compulsory; a small number of specialists at $\mathrm{CN}$ had the authority to define what music the pupils were exposed to, without involving the schools. As Kari Holdhus argues, the comprehensive "for all" philosophy and the mainly centralized concert production process often resulted in schools lacking a feeling of ownership of the programs (Holdhus and Espeland 2013, p. 17).

As a major national institution, $\mathrm{CN}$ had the power to select performers and shape performances according to the organization's aims. As an employer of mainly unorganized freelance musicians working on short-term contracts, there was obviously an imbalance of power. Still, a cultural program of this size would hardly work satisfactorily without promoting reciprocity, equality, and respect. It was crucial for $\mathrm{CN}$ producers to acknowledge and respect cultural codes and modes of performance so that musicians would feel comfortable adjusting to the particular school concert format. Many musicians were initially unfamiliar with playing for school children, so producers also acted as coaches, training them to become school concert performers in a Norwegian setting. 
When inviting performers from abroad, $\mathrm{CN}$ relied heavily on cultural knowledge and suggestions from immigrant communities, which often had their own cultural agendas and ambitions. Cooperating with $\mathrm{CN}$ was seen as beneficial, providing acknowledgement, some well-paid work for local musicians, and possibilities for inviting important artists to Norway. In the early years, the Pakistani community became especially involved, and various renowned performers were invited to Norway for school concerts and public concerts for the immigrant community, most notably Ustad Fateh Ali Khan, whose 1989 visit led to cooperation with saxophonist Jan Garbarek and the famous ECM album Ragas and Sagas (Garbarek et al. 1992).

\section{Tradition and Hybridity}

Music represents and identifies people, cultures, and communities. In $\mathrm{CN}$, there was a strong recognition of the important role traditional music played for the selfdefinition of immigrant communities. School concerts were aimed at making immigrant cultures visible, thereby empowering immigrant pupils through music they might identify with. One teacher in the Oslo area could relate how a concert with Hindustani classical music obviously made a difference for the Indian minority pupils at her school. She had observed how a previously "invisible" fourth-grader developed a new sense of pride and started to mark her cultural background by wearing traditional clothes on special occasions and even daring to sing an Indian song in front of the whole school at the annual closing ceremony ${ }^{9}$.

A conspicuous strategy in the multicultural music discourse of the 1990s was the promotion of crossover or hybrid expressions. CN and the Multicultural Music Centre especially encouraged "musical cooperation that crosses cultural boundaries" (Rikskonsertene 1992). The Ethnic Music Café in Oslo (1992-2001), through which many school concert performers were recruited, was an experimental stage where musicians of different cultural backgrounds would meet and play together in informal and sometimes improvised settings. This resulted in some surprising and striking cooperation projects, such as the widely praised "From Senegal to Setesdal," with musicians from Ivory Coast, Senegal, and Norway playing their traditional instruments in playful, overlapping, and contrasting ways (Berg, Cissokho, Sereba, Straume, \& Kvåle 1997).

When performers of different backgrounds play together for a child audience, it has both symbolic and educational dimensions; musical cooperation can be seen as a representation of human cooperation. When crossover music "works"-when different musical elements sound good together-it suggests that people of different backgrounds can "work" successfully together too. Trym Bjønnes, part of the Norwegian/Tanzanian duo Rafiki that performed for $\mathrm{CN}$, puts it as follows: "We

\footnotetext{
${ }^{9}$ Interview with Anne Moberg, project leader for The Resonant Community, 5 April 2018.
} 
are cultivating our musical friendship; we don't say it in words, but we try to show it through our music and the way we act together. This is the foundation of our entire concert" (Rikskonsertene 2009, n.p.).

CN's encouragement of crossover music projects has been met with certain criticism. Anne Ellingsen (2008) maintains that CN enforced a constructed hybridity rooted in state policies of integration, implying that performers were strategically combined, sometimes contrary to their own ambitions and preferences. According to Ellingsen, immigrant musicians were used as tools to create images of successful integration, thereby legitimizing state policies. More recently, a similar critique has been directed toward the Fargespill ${ }^{10}$ foundation (Hamre et al. 2012), which produces and promotes culturally diverse music and dance programs involving child refugees, Norwegian school children, and professional musicians. Fargespill has received increasing media attention and substantial government support for their programs featuring musical crossovers, often in the form of medleys combining Norwegian folk music and music of immigrant cultures. A heated debate arose after a critical article maintained that their performances are based on a staged formula that gives a false image of successful integration and, at worst, serves as a smokescreen diverting attention from the uglier sides of immigration policies, such as the forced return of young asylum seekers (Solomon 2016).

Such critical reactions raise issues of general interest related to cultural diversity in music education. Obviously, government-supported presentations of cultural crossover operate within a political sphere and must be understood as political utterances in the integration discourse. Still, as argued by the Fargespill organizers, live performances of intercultural music must be valued from social and artistic perspectives rather than solely the politics of representation. For the young refugees, participating in these crossover performances with Norwegian peers can provide an arena where they are more than their ethnicity, more than refugees. It may provide "a space where they feel empowered through artistic expression” (Moberg 2017, p. 46) and see themselves as artists, taking the emphasis off their adversities and status as minorities. Or, as Camilla Kvaal has pointed out in recent ethnographic research on Fargespill, the actual bodily engagement in processes of musical hybridity can create cross-fertilization or synergies, as well as affordances of companionship and compassion (Kvaal 2018).

\section{Art or Education?}

The policies governing the school concert programs were influenced by well-known music education discourses, especially the tensions between an artwork-oriented approach, emphasizing the intrinsic value of the music experience, and approaches referring to the more educational and instrumental justifications. In this respect, the

\footnotetext{
${ }^{10}$ Literally "Play of Colors." The official English name is Kaleidoscope.
} 
concert event involves a meeting between organizations and individuals with differing agendas and ideologies.

$\mathrm{CN}$ was always understood as an art institution rather than an educational institution, although the educational aspects are striking - not least in the cultural diversity programs, which initially were justified with reference to the role of education in shaping attitudes. School concerts with visiting musicians are professionally produced art experiences but take place within the school system, in an educational environment where art-based conceptions of quality are not necessarily relevant for creating a meaningful experience (Holdhus 2015b). When some schools failed to establish a sense of ownership of the concert event, it can be understood as the result of "a dominating rationale based on romantic aesthetic theories" (Holdhus and Espeland 2013, p. 1).

As Kari Holdhus maintains, an artwork-oriented paradigm may be problematic in a school concert setting, since it is not relational, but values artistic qualities more highly than qualities of human interaction (Holdhus 2015b). During CN's first 20 years (until 1987), an educational paradigm was dominating. Most CN staff had backgrounds as music teachers, and the cooperating schools were encouraged to include preparations for concerts in their regular music classes. From 1988, when a new leadership took over the $\mathrm{CN}$ concert department, the artwork-oriented paradigm gradually took hold. This happened at the same time as the multicultural programs were initiated, arguably emphasizing the divide between the ordinary concert promotion and the more instrumentally justified multicultural efforts. Western music (jazz, classical, or contemporary) was art and required no further justification, while music related to immigrants was largely justified as a tool for creating beneficial attitudes. Still, it is important to stress that all $\mathrm{CN}$ productions were widely recognized for their artistic quality. A guiding principle for concert producers was that political aims should not overshadow artistic requirements (Vandvik 2018, p. 160).

Until today, the artwork-oriented paradigm has had a strong anchoring in policies governing CN and other art programs for children. According to Holdhus (2015a), (based on observations from 2010/11), the CN program committee that evaluated and selected musicians for concert tours at that time understood "nonverbal presentation of absolute music" as more valuable than when children participate bodily or interact dialogically with performers, as was the case in most cultural diversity programs. Still, in recent years, the artwork-oriented paradigm has increasingly been challenged by theorizations that shift the point of focus from the artwork to the relation, encouraging the development of new performance modes that are dialogic, "polyphonic," and more comprehensive (Holdhus 2019, p. 243).

\section{Conclusion}

Although CN was closed in 2016, many Norwegian children still enjoy school concerts with visiting artists, now organized by AYAN. Music no longer has a special priority in national art programs, and the emphasis on cultural diversity has all but disappeared in the organization. Still, policies of cultural diversity continue to 
inspire and shape art programs in other fields and through other institutions, not least in recent music education programs involving young asylum seekers and refugees (Kvaal 2018; Roaldsnes 2016). To what extent these policies will have any significant influence on future art programs for children remains to be seen. However, whatever view we may have of presenting art to children, there is no reason to doubt that CN's policies of diversity over 30 years have influenced children's lives and their relationship to art, culture, and difference, through musical experiences that move, surprise, and thrill.

\section{References}

Agawu, K. (2003). Contesting difference. In M. Clayton, T. Herbert, \& R. Middleton (Eds.), The cultural study of music: A critical introduction (pp. 227-237). New York: Routledge.

Andersson, J., \& Hilson, M. (2009). Images of Sweden and the nordic countries. Scandinavian Journal of History, 34(3), 219-228.

Bamford, A. (2012). Arts and cultural education in Norway 2010/2011. Bodø: Nasjonalt senter for kunst og kultur i opplæringen.

Berg, K. B., Cissokho, S., Sereba, K., Straume, B., \& Kvåle, H. (1997). Frå Senegal til Setesdal [CD]. Oslo: Grappa.

Bergh, A. (2007). I'd like to teach the world to sing: Music and conflict trasformation. Musicae Scientiae (Special Issue 2007), 141-157.

Bjørnsen, E. (2009). Norwegian cultural policy: A civilising mission? Warwick: University of Warwick.

Booth, E. (2009). The music teaching artist's bible: Becoming a virtuoso educator. Oxford: Oxford University Press.

Borgen, J. S., \& Brandt, S. S. (2006). Ekstraordinaert eller selvfølgelig? Evaluering av Den kulturelle skolesekken i grunnskolen (Vol. 5/2006). Oslo: NIFU STEP.

Breivik, J.-K., \& Christophersen, C. (2013). Den Kulturelle skolesekken. Oslo/Bergen: Kulturrådet, Fagbokforlaget.

Carson, C., \& Westvall, M. (2016). Intercultural approaches and "Diversified normality" in music teacher education: Reflections from two angles. Action, Criticism, and Theory for Music Education, 15(3), 37-52.

Ellingsen, A. (2008). Music and ethnic integration in Norwegian state policies. Oslo: Department of Social Anthropology, Faculty of Social Sciences Unipub.

Garbarek, J., Khan, F. A., Hussain, U. S., Khan, U. N. A., Deeyah, T., Katché, M., \& Eicher, M. (1992). Ragas and sagas [CD]. München: ECM.

Green, L. (2003). Why 'Ideology' is still relevant for critical thinking in music education. Action, Criticism, and Theory for Music Education, 2(2), 2-20.

Hamre, O., Saue, S., Bræin, I., Dillan, G., Burgess, R., \& Fargespill. (2012). Kaleidoscope. Bergen: Stiftelsen Fargespill.

Holdhus, K. (2015a). Skolekonsertene og skolekonteksten: Mellom verkorientering og kunstdidaktikk. Nordisk Musikkpedagogisk Forskning: Årbok, 16, 294-315.

Holdhus, K. (2015b). Skolekonserter - Relasjonelle kunstdidaktiske praksiser? Studia Musicologica Norvegica, 41, 87-105.

Holdhus, K. (2019). The polyphony of musician-teacher partnerships: Towards real dialogues? Thinking Skills and Creativity, 31, 243-251. https://doi.org/10.1016/j.tsc.2019.01.001.

Holdhus, K., \& Espeland, M. (2013). The visiting artist in schools: Arts based or school based practices? International Journal of Education \& the Arts, 14 (special issue 1). Retrieved July 14, 2020 from http://www.ijea.org/14si1/. 
Kallio, A. A., \& Väkevä, L. (2017). Inclusive popular music education? In F. Holt \& A.-V. Kärje (Eds.), The Oxford handbook of popular music in the Nordic countries (pp. 75-89). New York: Oxford University Press.

KKD. (2007). St.meld. nr. 8(2007-2008) A cultural rucksack for the future. Ministry of Culture and Church Affairs.

Knudsen, J. S. (2013). Children's concert experience: An intercultural approach. In G. Boldt \& F. McArdle (Eds.), Young children, pedagogy and the arts: Ways of seeing (pp. 169-186). New York/London: Routledge.

Knudsen, J. S., \& Berkaak, O. A. (1998). Følg tonen verden rundt! Prosjekt flerkulturelle musikkfors $\phi k$ i Akershus: Evalueringsrapport. Oslo: Akershus fylkeskommune.

Korum, S. (2019). Bang drums until the cement softens: International music collaboration in Palestine. In S. Böhnisch \& R. M. Eidsaa (Eds.), Kunst og konflikt: Teater, viusell kunst og musikk I kontekst (pp. 207-266). Universitetsforlaget. https://doi.org/10.18261/ 9788215032344-2019-10.

Korum, S., \& Subramaniam, B. (2020). Culture in international development: The role of Concerts Norway in the India-Norway music cooperation (2002-2017). Development in Practice, 1-15. https://doi.org/10.1080/09614524.2020.1732301.

KUF. (1996). Lareplanverket for den 10-årige grunnskolen. Oslo: Det kongelige kirke- utdannings og forskningsdepartement.

Kumashiro, K. K. (2002). Troubling education: Queer activism and antioppressive education. New York: Routledge.

Kunnskapsdepartementet. (2006). Lareplanverket for Kunnskapsløftet. Oslo: Utdanningsdirektoratet.

Kunnskapsdepartementet. (2016). Fag - fordypning - forståelse: En fornyelse av Kunnskapslфftet. Oslo: Utdanningsdirektoratet.

Kvaal, C. (2018). Crossing affordances: Hybrid music as a tool in intercultural music practices. Norwegian Academy of Music.

Lundberg, D., Malm, K., \& Ronström, O. (2003). Music media multiculture - Changing musicscapes. Stockholm: Svenskt Visarkiv.

Moberg, F. (2017). Response to Thomas Solomon's article "The play of colors: Staging multiculturalism in Norway". Danish Musicology Online, 8. https://www.danishmusicologyonline.dk/ arkiv/arkiv_dmo/dmo_08/dmo_08_artikel_04.pdf

Rabkin, N. (2011). Teaching artists and the future of education. Teaching Artist Journal, 10(1), 5-14. https://doi.org/10.1080/15411796.2012.630633.

Rikskonsertene. (1992). Norsk Flerkulturelt Musikksenter (information pamphlet). Oslo: Rikskonsertene.

Rikskonsertene. (2009). Mangfoldige skolekonserter [DVD]. Oslo: Rikskonsertene.

Roaldsnes, M. (2016). Musikk som avleiing og kjelde til positive emosjonar. In K. Stensæth, V. Krüger, \& S. E. Fuglestad (Eds.), I transitt - mellom til og fra (pp. 157-173). Oslo: NMH-publikasjoner.

Rønningen, A. (2015). Historier fra Etnia. Representasjon av kulturell annerledeshet i lærebøker i musikk for norsk ungdomsskole. Nordic Research in Music Education, 15, 121-152.

Ronström, O. (1995). Sounds as signs. On the role of musical instruments and folk music in multicultural Sweden. In E. Stockman, A. Michel, \& B. Kjellström (Eds.), Studia instrumentorum musicae popularis (Vol. XI, pp. 91-96). Stockholm: Musikhistoriska museet.

Schippers, H. (2010). Facing the music. Finnish Journal of Music Education, 13(1), 39-44.

Skyllstad, K. (1993). Summary report. The resonant community - Fostering interracial understanding through music. Oslo: Norwegian Concert Institute.

Skyllstad, K. (2004). Creating a culture of peace - The performing arts in interethnic negotiations. In F. E. Jandt (Ed.), Intercultural communication: A global reader. Thousand Oaks: Sage.

Solomon, T. (2016). The play of colors: Staging multiculturalism in Norway. Danish Musicology Online, Special edition, 187-201.

Tvedt, T. (2005). Det nasjonale godhetsregimet: Om utviklingshjelp, fredspolitikk og det norske samfunn. In Det norske samfunn (pp. 482-510). Oslo: Gyldendal Akademisk. 
UN General Assembly. (1989). Convention on the rights of the child (United Nations Treaty Series, vol. 1577, p. 3). Accessed 11 Nov 2019 from https://www.ohchr.org/en/professionalinterest/ pages/crc.aspx

Vandvik, T. (Ed.). (2018). "For barn og unge" - Utdrag fra Rikskonsertenes historie. Oslo: Akademisk Publisering.

Jan Sverre Knudsen is a professor of music at Oslo Metropolitan University, Faculty of Education and International Studies. His research and publications focus on the role of musical practices in immigrant communities, intercultural concert promotion in schools and kindergartens, and issues related to nationality and ethnicity in music education. Knudsen is currently engaged in FUTURED, a major research project investigating music in teacher education.

Open Access This chapter is licensed under the terms of the Creative Commons Attribution 4.0 International License (http://creativecommons.org/licenses/by/4.0/), which permits use, sharing, adaptation, distribution and reproduction in any medium or format, as long as you give appropriate credit to the original author(s) and the source, provide a link to the Creative Commons license and indicate if changes were made.

The images or other third party material in this chapter are included in the chapter's Creative Commons license, unless indicated otherwise in a credit line to the material. If material is not included in the chapter's Creative Commons license and your intended use is not permitted by statutory regulation or exceeds the permitted use, you will need to obtain permission directly from the copyright holder. 